CZASOPISMO INŻYNIERII LĄDOWEJ, ŚRODOWISKA I ARCHITEKTURY JOURNAL OF CIVIL ENGINEERING, ENVIRONMENT AND ARCHITECTURE

JCEEA, t. XXXIII, z. 63 (4/16), październik-grudzień 2016, s. 365-374

Anita ORCHOWSKA ${ }^{1}$

\title{
ARCHITEKTONICZNE ROZWIĄZANIA Z ZASTOSOWANIEM „RE-UŻYCIA” PEYT PREFABRYKOWANYCH
}

\begin{abstract}
Problemy architektoniczne i urbanistyczne blokowisk są powszechnie znane w krajach europejskich. Jednym $\mathrm{z}$ prób ich rozwiązania jest odnowa związana z polepszeniem środowiska mieszkaniowego i technicznego stanu zabudowy. Oprócz metody zachowawczej, w krajach Europy zachodniej prowadzi się wyburzenia niezamieszkałych i zdegradowanych budynków lub obniża się ich wysokość i tektonikę zmieniając w sposób zasadniczy estetykę zabudowy. Artykuł przedstawia prace eksperymentalne przeprowadzane w Niemczech związane z jedną z metod ponownego wykorzystania prefabrykowanych płyt betonowych, która polega na budowie przy ich udziale „nowych” budynków mieszkalnych. Jakie są architektoniczne możliwości rozwiązań i ich korzyści oraz negatywne strony tej metody? Re-użycie płyt betonowych jest alternatywą w rozwiązaniach architektonicznych i budowanych dla istniejącej tkanki mieszkaniowej powstałej w technologii uprzemysłowionej. Nowa zabudowa spełnia standardy ekologiczne i daje możliwość wprowadzenia oszczędności na różnym etapie inwestowania i funkcjonowania budynku. W efekcie zmian notuje się generalną poprawę jakości życia, warunków higienicznych zabudowy i jej pozytywnego wizerunku na tle rozwoju terenów mieszkaniowych miasta. Problem czasowości w architekturze pojawia się tu w aspekcie przemiany uwarunkowań społecznych i środowiskowych, jako podążanie za zmieniającymi się standardami i potrzebami współczesnego życia. Wykorzystanie tej metody w Polsce jest trudne do osiągnięcia, ale może stanowić podstawą rozważań badawczych w tym zakresie.
\end{abstract}

Słowa kluczowe: budynki mieszkalne, architektura, re-użycie, środowisko mieszkaniowe

\section{Wprowadzenie}

Po okresie intensywnej pracy nad tworzeniem programów i strategii rozwoju wielkich osiedli mieszkaniowych miast europejskich, których celem było utrzymanie istniejących zasobów i polepszenie ich standardów, przyszedł czas na inne spojrzenie na ten znany od wielu lat problem. Niemieckie działania

\footnotetext{
${ }^{1}$ Anita Orchowska, Politechnika Warszawska, Wydział Architektury, Zakład Architektury, Wnętrz i Form Przemysłowych, ul. Koszykowa 55 , 00-659 Warszawa; tel. 22 6282887; orchowska@poczta.fm
} 
w dziedzinie modernizacji osiedli prefabrykowanych, będące przykładem modelowym w tym zakresie, nie wyeliminowały całkowicie problemu występujących w dużej ilości pustostanów. Pomimo stworzenia finansowego wsparcia ze strony Państwa oraz zaangażowania lokalnych społeczności mamy wciąż do czynienia z postępującymi wyludnieniami budynków, zwłaszcza we wschodnich częściach Niemiec. Zmiana miejsca zamieszkania ludności osiedli wiąże się z chęcią podniesienia statusu społecznego i osiągnięcia lepszych warunków mieszkaniowych, odcięcia się od niechlubnej historycznie zabudowy, a także migracją zarobkową do innych rejonów kraju. Zmieniające się standardy mieszkaniowe i potrzeby społeczne w miastach współczesnej Europy zmuszają projektantów do rozwiązań kreatywnych i nowoczesnych związanych z mieszkalnictwem, a równocześnie zwracających uwagę na ochronę naszego środowiska zamieszkania.

Jednym z działań modernizacyjnych w Europie dotyczącym osiedli jest wymiana substancji budowlanej w częściowym lub całościowym zakresie. Znane są działania związane z pomniejszaniem wysokości budynków, fragmentaryczną rozbiórką ich części czy całkowitymi wyburzeniami, w celu wprowadzenia nowej zabudowy. Sporo miejsca zajmuje zagadnienie ponownego wykorzystania substancji budowlanej - wielkopłytowej w budownictwie. Z jednej strony zwolennicy tego typu rozwiązań propagują ilość zalet wynikających z tej metody odnowy oraz jej bezpośrednie korzyści, z drugiej strony istnieje mocna świadomość braku możliwości trwałego przekształcenia środowiska mieszkaniowego bez jego radykalnych zmian.

\section{Uwarunkowania}

Projekty teoretyczne i eksperymentalne rozwiązania architektoniczne powstają w Niemczech od lat, od momentu kiedy nastąpiło przyłączenie wschodnich landów i ruszył proces modernizacji terenów mieszkaniowych w 1989 roku. Wkrótce problem ten stał się jednym z najważniejszych elementów polityki mieszkaniowej państwa. Temat rozbiórki jest przedmiotem projektów badawczych prowadzonych przez instytucje naukowe wspierane przez programy finansowane przez państwo ${ }^{2}$.

Pierwszym problemem od lat 90-tych do chwili obecnej jest ogromna i narastająca liczba pustostanów. Niemcy przewidywali, że do 2010 roku trzeba będzie rozebrać 350 tysięcy mieszkań w budynkach prefabrykowanych ${ }^{3}$ [1],

\footnotetext{
${ }^{2} \mathrm{~W}$ modernizację zaangażowanych jest wiele instytucji m.in.: Senat Berlina, ,Uniwersytet Techniczny (TU Berlin), Instytut Rozwoju Regionalnego i Strukturalnego Planowania (IRS) oraz wiele inny instytucji badawczych z całego kraju. Funkcjonuje specjalistyczny program nt. możliwości ponownego re-użycia zdemontowanych elementów prefabrykowanych w budownictwie mieszkaniowym finansowany przez Urząd Federalny dla Budownictwa i Planowania Regionalnego (BBR) ${ }^{3}$ Powody jak szacują eksperci są następujące: niski odsetek urodzeń we wschodniej części Niemiec, kurczenie się populacji i brak miejsc pracy
} 
a następnie w ciągu kolejnych lat zlikwidować ok. 200 tysięcy lokali ${ }^{4}$ [2]. Wysokie koszty utrzymania budynków wiążą się z dużymi kosztami utrzymania opustoszałych mieszkań, które często pozostają w dobrym stanie do momentu rozbiórki. W takich miejscach istnieje zagrożenie zasiedlenia przez osoby o niestabilnej sytuacji finansowej i powstawanie tzw. ,getta dla ubogich”. Zazwyczaj wzrasta też niezadowolenie z panującej sytuacji mieszkaniowej tych, którzy nie mogą pozwolić sobie na przeprowadzkę. Według opinii wielu środowisk naukowych opartych na obserwacjach dotychczasowych przekształceń nie da się trwale zmienić środowiska mieszkaniowego poprzez kosmetykę fasady, wzbogaceniem oferty mieszkaniowej czy budowę handlowo - rekreacyjnych centrów dla mieszkańców. Podważa to sens prowadzonej od lat modernizacji architektoniczno - urbanistycznej tych osiedli. Struktura budynków wykonanych w technologii wielkopłytowej pozostaje w dużym stopniu jednolita i monotonna. Brak też stosowanych dotąd mało kosztownych pomysłów, które mogłyby doprowadzić do zróżnicowanych i ambitnych form architektonicznych [3].

Tymczasem demontowane płyty betonowe wykorzystuje się do wznoszenia zabudowy mieszkaniowej jednorodzinnej, małych domów mieszkalnych, na tej samej działce, w jej pobliżu lub w innej lokalizacji. W taki sposób mogą powstać budynki jednorodzinne wolnostojące, szeregowe oraz niska intensywna zabudowa innego typu. Dzięki temu kształtuje się indywidualny charakter środowiska mieszkaniowego zgodnie z zapotrzebowaniem mieszkańców, z przydomowymi ogródkami i małą skalą rozdrobnionej zabudowy. Budynki takie prezentują znacznie wyższe jakości architektoniczne, spotykają się z powszechną akceptacją użytkowników oraz są korzystne środowiskowo i atrakcyjne finansowo.

\section{Ocena technologii}

Do zalet i bezpośrednich korzyści idei ,re-użycia” płyt betonowych w budownictwie mieszkaniowym zaliczyć można:

- oszczędności na rożnym poziomie realizacji inwestycji; przy ponownym wykorzystaniu materiału budowlanego w postaci płyt betonowych, koszt stanu surowego nowych budynków jest o ok. 30\% mniejszy [3]; przy powtórnej zabudowie parcel z istniejącą infrastrukturą - nie ma potrzeby wykorzystywania nowego terenu pod inwestycje; występują mniejsze koszty transportu i usuwania materiałów budowlanych,

- użycie zachowanych $\mathrm{w}$ dobrym stanie płyt betonowych $\mathrm{w}$ znacznym stopniu przyspiesza budowę obiektu, długa żywotność płyt, które są przesuszone daje możliwość postawienia obiektu w stanie surowym w ciągu kilku dni; elementy użyte są do ścian zewnętrznych konstrukcyjnych, wewnętrznych działowych,

\footnotetext{
${ }^{4}$ Niemiecki rząd wydał na rozbiórkę budynków do 2010 roku 2,6 mld euro, a w zamierzeniach miały być kolejne 3 mld euro
} 
jako podłogowa i konstrukcja dachu; prostszy od oryginalnego sposób spinania płyt daje możliwość łatwiejszego demontażu w dowolnym czasie użytkowania; swobodne kształtowanie wnętrza i podział otworów okiennych i drzwiowych uzyskuje się poprzez przycinanie elementów betonowych [4],

- kreowanie atrakcyjnego środowiska mieszkaniowego w sposobie zabudowy, jako zespołu domów lub indywidualnych budynków jednorodzinnych, przy jednoczesnym zachowaniu niewysokiej ceny mieszkań,

- wizualna zmiana miejsca - osiedla wielkopłytowego, fragmentu dzielnicy, miasta poprzez wprowadzenie różnorodnej struktury budynków i infrastruktury terenu,

- możliwość pozostania mieszkańców w dobrze im znanym środowisku, w pobliżu tej samej szkoły, przedszkola, miejsca pracy itd.,

- wprowadzenie zróżnicowanej struktury społecznej na osiedlu mieszkaniowym,

- uwzględnienie aspektów ekologicznych w zakresie: oszczędności związanych $\mathrm{z}$ wykorzystaniem niezainwestowanych terenów np. zielonych pod nowe budownictwo mieszkaniowe; ograniczenia w ruchu ulicznym dzięki dogęszczeniu zabudowy i zastosowaniu np. segregacji ruchu pieszego od jezdnego; możliwości zastosowania technologii proekologicznych przy budowie nowych budynków, bez problemów związanych ze starą zabudową,

- występowanie nieograniczonej ilości budulca - płyt betonowych, które można odzyskiwać z planowanych do rozbiórki obiektów.

Do negatywnych aspektów re-użycia zaliczyć można ograniczenia architektoniczne w kształtowaniu bryły budynku spowodowane stałymi i niezmiennymi podstawowymi wymiarami płyt. Kreatywność w formowaniu bryły powinna zbliżać się do uzyskania prostoty i jasnych zasad budowy elewacji budynku. Duże znaczenie ma również odległość budowy od miejsca rozbiórki. Ze względu ciężar betonu zamierzenie jest opłacalne w promieniu $300 \mathrm{~km}$, gdyż niskie koszty budowy wzrastają znacznie podczas odległego transportu. Najlepiej, jeśli betonowe płyty użyte są w krótkim czasie po rozbiórce, ponieważ ich magazynowanie jest bardzo kłopotliwe. Przechowywanie powinno odbywać się przy zastosowaniu drewnianych przekładek w formie podpór, aby ograniczyć stykanie się płyt i ich pękanie pod własnym ciężarem ${ }^{5}$ [5].

\footnotetext{
${ }^{5}$ Inżynierowie z Uniwersytetu Technicznego w Berlinie tłumaczą, że firmy zajmujące się rozbiórką nie są zbyt ostrożne przy umieszczaniu płyt na podporach, a często spadające płyty naruszają swą konstrukcję
} 


\section{Przykłady}

Poniżej przedstawiono przykłady projektów pilotażowych i realizacji rozwiązań architektonicznych. Realizacje dotyczą modernizacji z zastosowaniem re-użycia płyt rozbiórkowych w miejscu zabudowy lub nowych budynków na położonej w innej lokalizacji działce.

\subsection{Przebudowa i modernizacja wieżowców - osiedle Sachsendorf w Cottbus}

Projekt i realizacja dotyczy wyburzenia znacznej części 11-kondygnacyjnego wieżowca w Cottbus przy ul. Chopinstrasse $1 / 3^{6}$ oraz recyclingu części składowych budynku - płyt prefabrykowanych. Dwa z trzech istniejących w tym miejscu obiektów zostały odnowione ${ }^{7}$, trzeci poddano rozbiórce. Wykorzystując fragmenty przyziemia oraz pierwszej kondygnacji istniejącego wieżowca, a także teren w jego pobliżu powstało pięć budynków mieszkalnych, w których znajduje się od jednego do kilku apartamentów i mieszkań dwupoziomowych [3]. 2 i 3 kondygnacyjne obiekty tzw. ,wille miejskie” zostatały wzniesione przy ponownym wykorzystaniu płyt betonowych $\mathrm{z}$ rozbiórki. W tym przypadku użyto ok. 1/3 materiału rozbiórkowego ${ }^{8}$. Proponowane zagospodarowanie w otoczeniu obiektów stosuje podniesiony poziom terenu ponad istniejącą po wyburzeniu pierwszą kondygnację. Mieszkania są urozmaicone, 2-, 3- i 5-cio pokojowe w zależności od zapotrzebowania na rynku. Część z nich z przeznaczeniem na wynajem. Na parterze przydomowe ogródki przynależą do mieszkań. Zaproponowana architektura charakteryzuje się prostotą rozwiązań. Zastosowany schodkowy układ budynku urozmaica jego estetyczny charakter, umożliwia zmniejszenie zacienienia w bliskim sąsiedztwie, a obniżenie skali zabudowy zapewnia wgląd w otaczającą zieleń. Nowe obiekty diametralnie różnią się wysokością od pozostałej zabudowy. Najbliższe otoczenia inwestycji prezentuje wysoką jakość rozwiązań urbanistycznych i atrakcyjny wizerunek przestrzeni publicznej ze ścieżkami, segregacją ruchu, przestrzenią lokalnej rekreacji i bogatą zielenią. Ludzka skala zabudowy zapewnia lepsze doświetlenie przestrzeni i odpowiednie przewietrzanie oraz lepsze warunki wegetacji roślin. Budynki spełniają najwyższe standardy ekologiczne i są tańsze o $15-20 \%$ od porównywalnego obiektu wykonanego z całkowicie nowych materiałów [6].

\footnotetext{
${ }^{6}$ Autorem projektu jest biuro Zimmermann + Partner architekten DBA w Cottbus. W roku 1998 rozpoczęto projekt modernizacji grupy budynków 11- kondygnacyjnych, 2001 roku miał miejsce początek demontażu płyt prefabrykowanych w obiekcie i budowa nowych budynków, w 2002 roku kompleks został oddany do użytku. Według niemieckich źródeł ten projekt pilotażowy, był pierwszą próbą zastosowania technologii re-użycia płyt rozbiórkowych

${ }^{7}$ Odnowa była kompleksowa począwszy od przebudowy mieszkań, części wspólnych, zmodernizowano elewacje, utworzono nowe wejścia, loggie oraz wprowadzono rozwiązania proekologiczne (m.in. ogniwa fotowoltaiczne)

${ }^{8}$ Pozostała część uległa zniszczeniu
} 


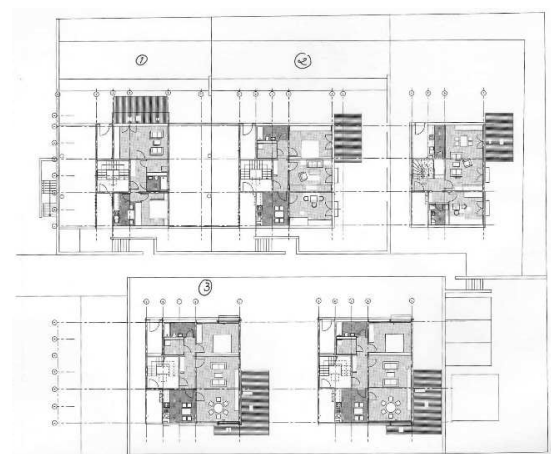

Rys. 1. Plan mieszkań - Cottbus. Dzięki uprzejmości biura Zimmermann + Partner architekten DBA

Fig. 1. Housing plan - Cottbus. Coutresy of Zimmermann + Partner architekten DBA

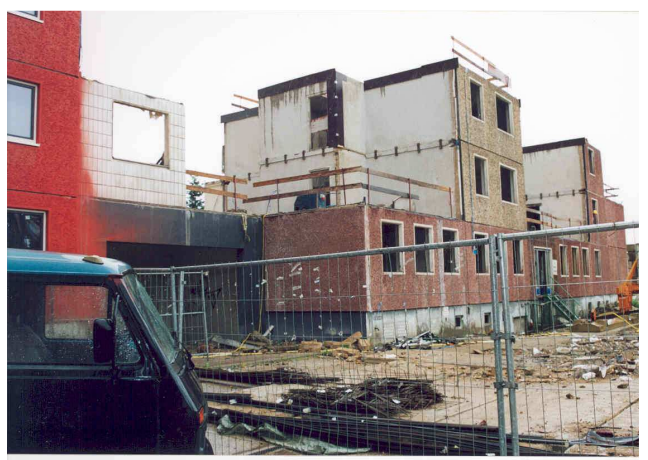

Rys. 2. Przebudowa budynków - Cottbus. (Autor zdjęcia: Anita Orchowska)

Fig.2. Reconstruction of buildings - Cottbus. (Author photo: Anita Orchowska)

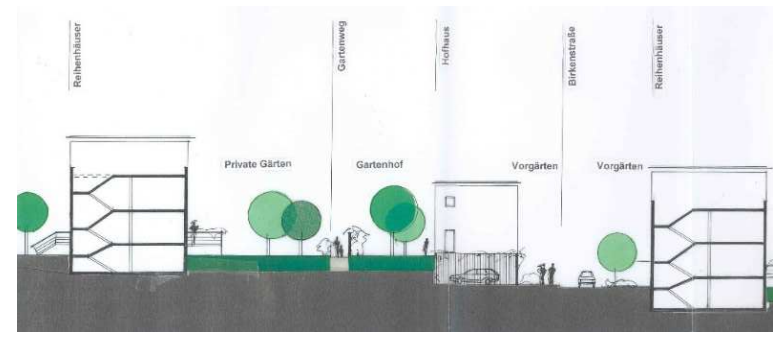

Rys. 3. Przekrój - Kitzscher. Dzięki uprzejmości biuro Meyer-Miethke \& Partners Architekten und Ingenieure

Fig. 3. Section - Kitzscher. Coutresy of Meyer-Miethke \& Partners Architekten und Ingenieure

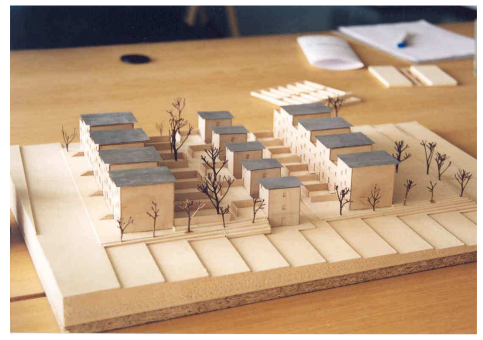

Rys. 4. Model - Kitzscher. (Autor zdjęcia: Anita Orchowska)

Fig. 4. Model - Kitzscher. (Author photo: Anita Orchowska)

\subsection{Projekt przebudowy budynków mieszkalnych w Kitzscher}

Projekt zakładał częściowy demontaż dwóch opustoszałych budynków mieszkalnych 5-kondygnacyjnych w miejscowości Ktzscher przy ul Birkenstrasse i Strasse des Friedens ${ }^{9}$. Części obiektów - 2 lub 3 górne kondygnacje miały zostać zdemontowane, a uzyskane w ten sposób płyty miały stanowić materiał do budowy pojedynczych segmentów - domów jednorodzinnych w pasie równoległym pomiędzy istniejącą zabudową. Rozebrane bloki miały uzyskać urozmaiconą architekturę, a poprzez dodatkowe obniżenie części górnej kondygnacji

\footnotetext{
${ }^{9}$ Projekt wykonany przez biuro Meyer-Miethke \& Partners Architekten und Ingenieure w Espenhain w roku 2001
} 
nawiązywać do nowych, pojedynczych budynków wewnątrz zabudowy. Zmodernizowane mieszkania uzyskały duże tarasy oraz nowy podział wewnętrznej powierzchni użytkowej. Projekt zakładał budowę małych domów jednorodzinnych wolnostojących, które posiadają przydomowe ogródki i w skali zabudowy tworzą przestrzeń typowego osiedla domów jednorodzinnych. Do budowy miały posłużyć zdemontowane płyty sąsiednich obiektów. W projekcie zaproponowano różnicę poziomów, wynikającą $\mathrm{z}$ istniejącego zagospodarowania. Teren w projekcie podwyższono w strefie rekreacji, a obniżono od strony uliczki wjazdowej [3]. Zmiany środowiska zabudowy sztywnych bloków w przyjazną architektonicznie strukturę były w założeniach bardzo atrakcyjne. Nie doszło jednak do realizacji projektu. Obecnie w tym rejonie po wyburzeniach dwóch budynków pozostał teren zielony, który służy jako rekreacja dla całej przestrzeni funkcjonującego osiedla.

\subsection{Projekty pilotażowych domów wolnostojących pod Berlinem ${ }^{10}$}

Budynki, które powstały w ramach projektu wykorzystywały komponenty betonowe w postaci paneli ścian nośnych i sufitowych oraz elementów podłogi. Płyty stanowią same w sobie konstrukcję nośną, dodatkowe wzmocnienia nie były potrzebne. Elementy łączono stalowymi kotwami, które mogą przenosić duże obciążenia. Takie zastosowanie gwarantowało możliwość demontażu płyt np. po zakończeniu ich użytkowania. W przypadku tego projektu oprócz korzyści środowiskowych i ekonomicznych bardzo istotne okazały się możliwości dowolnego kształtowania architektury. Każdy z obiektów miał indywidualne plany oraz różnił się kształtem kubatury. Używane do budowy zdemontowane płyty wewnętrzne mogły być w dowolny sposób pocięte zgonie z zapotrzebowaniem i wizją architekta. Cięcie oryginalnych ścian paneli zewnętrznych okazało się mniej odpowiednie, gdyż składające się z kilku warstw elementy przy nacinaniu traciły swoją jednorodność. W ten sposób uzyskano 95\% struktury konstrukcyjnej budynku, a czas jej powstawania ograniczał się do kilku dni. Zatem budowa domu do stanu wykończenia, z wykonaniem powłoki izolacyjnej i ochronnej mogła trwać jedynie 3 miesiące [4]. Poza oszczędnością kosztów inwestycji i czasu budowy warto wspomnieć o zaletach materiałowych samych paneli betonowych. Jako materiał budowlany, beton doskonale magazynuje ciepło, jest dźwiękochłonny i tworzy przyjemny klimat we wnętrzu [1], co jest ważnym aspektem użytkowym. Jak twierdzą inżynierowe współpracujący przy powstawaniu zabudowy, standardy techniczne obiektów są bardzo dobre, nie odbiegają niczym od innych, nowoczesnych technologii. Ich dodatkowym atutem jest $\mathrm{w}$ razie konieczności możliwość łatwej przebudowy, zmiany obrysu i struktury przestrzennej, bez uszczerbku w konstrukcji obiektu [7].

${ }^{10}$ Budynki zaprojektowali architekt Herve Biele z biura Conclus, przy współpracy Instytutu Ochrony i Modernizacji Budynków Technicznego Uniwersytetu w Berlinie - IEMB TU Berlin 
W ramach projektu powstały trzy obiekty ${ }^{11}$ jednym z nich był dom „Z” zlokalizowany w Mehrow pod Berlinem. Jest to dom wolnostojący o wielkości $212 \mathrm{~m}^{2} \mathrm{z}$ garażem na dwa miejsca parkingowe. Układ przestrzenny domu proponuje ciekawy rozkład pomieszczeń wraz z przestrzenią wspólną i indywidualnymi pokojami oraz atrakcyjny lecz nieskomplikowany wygląd zewnętrzny ${ }^{12}$. Budynek został zbudowany z płyt rozbiórkowych pochodzących z 11-kondygnacyjnego wieżowca berlińskiej dzielnicy Marzahn [7]. Do budowy zużyto panele poziome sufitowe w ilości 27 sztuk i pionowe wewnętrzne ścienne - 22 sztuki. Oprócz tego, powstały jeszcze: domy „L” w Schildow oraz „K” w Schoneiche pod Berlinem [4].

b) dom w Muhlhausen

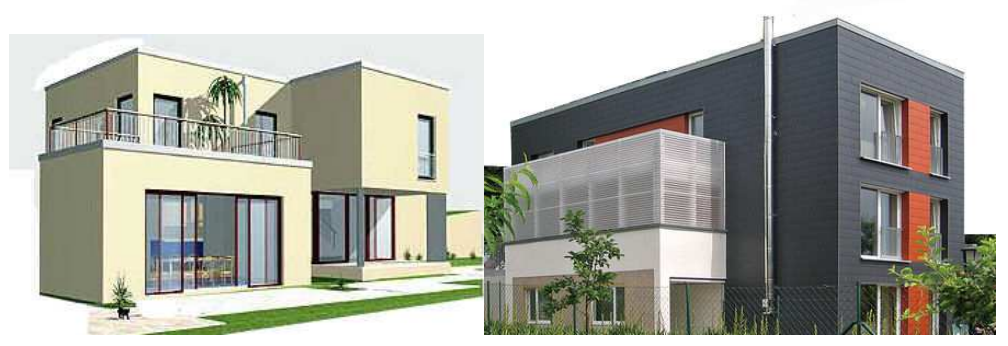

Rys. 5. Przykłady przebudowanych budynków, na podstawie [2, 5]

Fig. 5. Examples of reconstructed buildings, based on $[2,5]$

\subsection{Dom mieszkalny wolnostojący - ,shoes-box” pod Dreznem}

Budynek wolnostojący zbudowany został w Muhlhausen w pobliży Dre$z^{13}{ }^{13}$. Płyty pochodzące $\mathrm{z}$ rozbiórki bloków przetransportowano na miejsce budowy ${ }^{14}[2]$. Budynek nie przypomina w niczym bloków z jakich powstał. Reprezentuje on nowoczesną architekturę, a podłużna 3-kondygnacyjna bryła nadaje atrakcyjny i dynamiczny wygląd całości architektonicznego założenia. Duże otwory okienne zapewniają większy dostęp światła do wnętrza budynku.

\footnotetext{
${ }^{11}$ Wszystkie domy jednorodzinne powstały w 2005 roku

${ }^{12}$ Zastosowano nowoczesne technologie: pompę ciepła - ogrzewanie podłogowe, dodatkową warstwę izolacyjną zewnętrznej. Jak twierdzi projektant Herve Biele dom nie wymaga ogrzewania przez okres do $80 \%$ w ciągu roku

${ }^{13}$ Autorem projektu jest Norman Hose. Dom został zbudowany w roku 2010

${ }^{14}$ Koszt przewozu 58 elementów betonowych wyniósł 5000 euro
} 


\section{Wnioski}

Eksperymentalne metody kształtowania zabudowy mieszkaniowej z zastosowaniem re-użycia płyt betonowych pozyskanych z rozbiórki obiektów są rozwiązaniem alternatywnym dla zachowawczych prób poprawy estetyki zabudowy i przeprowadzanych całościowych wyburzeń. Zbudowane w ten sposób obiekty architektoniczne mogą prezentować nie tylko różne walory estetyczne i nowoczesny wygląd nie przypominający starych bloków mieszkalnych, ale rozmaite rozwiązania przestrzenne i techniczne przy wsparciu technologii proekologicznych. Zarówno projekty eksperymentalne jak i realizacje w miejscu starych obiektów kształtują nowy wizerunek architektury mieszkaniowej i znacznym stopniu przyczyniają się do poprawy jakości życia i warunków higienicznych zabudowy. Powstające oszczędności środowiskowe i ekonomiczne w projektach realizujących ponowne użycie substancji budowlanej wielkopłytowej, wpisują tę metodę w ważny nurt architektury tworzonej z poszanowaniem środowiska naturalnego. W ten sposób nie tylko oszczędza się energię, chroni zasoby naturalne lecz uczestniczy w procesie recyklingu materiałów budowlanych. Cykl użytkowy zastosowanych $\mathrm{w}$ przedsięwzięciach płyt może być dalej kontynuowany. Prezentowany w artkule obszar wiedzy jest na początku swej drogi badawczej, jednak w przyszłości można spodziewać się efektów oszczędnościowych i środowiskowych zwłaszcza porządkujących tereny pustoszejących blokowisk. Najważniejszymi aspektami tej technologii, które wymagają szczegółowego opracowania jest jakościowe rozpoznanie pozyskiwanych materiałów do rozbiórki, projekty architektoniczne skorelowane z technologią, logistyka związana z rozbiórką, przewozem i montażem oraz stworzenie odpowiednich regulacji finansowych, prawnych i budowlanych [8]. Re-użycie czeka wciąż na rozpowszechnienie, choć autorzy projektów sygnalizują stały wzrost zainteresowania tą metodą, tym bardziej, że materiału rozbiórkowego jest pod dostatkiem i jest on w bardzo dobrym stanie technicznym.

W Polsce nie mamy problemu pustostanów i nie musimy jeszcze zadawać sobie pytania jak nasi zachodni sąsiedzi, co zrobić z wciąż zdrowymi płytami pozostałymi z rozbiórki. Jednak takie doświadczenia pozwalają spojrzeć na zagadanie blokowisk z innej, niż tej znanej strony - nieodwracalnej, niechlubnej przeszłości, lecz w kierunku rozważań badawczych nt. możliwości wykorzystania istniejącego potencjału współczesnych miast i osiedli.

\section{Literatura}

[1] http://archiv.pressestelle.tu-berlin.de/pi/2005/pi161.htm \{dostęp 18.06.2016\} .

[2] http://www.csmonitor.com/World/Global-News/2010/0308/Germany-Recyclingcommunist-housing-blocks-into-modern-homes \{dostęp 11.06.16\}. 
[3] Orchowska A.: Aspekt urbanistyczny i architektoniczny odnowy zespołów mieszkaniowych II połowy XX wieku, praca doktorska, Kraków 2002.

[4] https://betongelit.files.wordpress.com/2009/07/werkinfo.pdf \{dostęp 08.06.2016\}.

[5] http://www.spiegel.de/international/recycling-architectural-disasters-a-communistblock-house-renaissance-a-367335.html \{dostęp 08.06.2016\}.

[6] http://www.werkstatt-stadt.de/de/projekte/58/ \{dostęp 10.06.2016 r.\}.

[7] https://www.theguardian.com/artanddesign/2005/nov/14/architecture.germany $\{$ dostęp 18.0616$\}$.

[8] http://www.bbsr.bund.de/BBSR/EN/Publications/CompletedSeries/IEMB/2006_200 7/DL_3_2007.pdf?_blob=publicationFile\&v=2 \{dostęp 20.06.16\}.

\section{ARCHITECTURAL SOLUTIONS WITH REUSE OF PREFABRICATED CONCRETE SLABS}

\section{S u m m a r y}

The problems of architectural and urban housing estates are well known in European countries. One of the attempt to solve them is renewal associated with improvement of housing environment and the technical condition of building estate. Western European countries in addition to conservative methods carried out the demolition of abandoned and degraded buildings or they lowered their height and tectonics in order to fundamentally change the aesthetics of buildings. The article presents experimental works in Germany related to one of the methods for the re-use of prefabricated concrete slabs, which simply involves reusing them in the construction of "new" residential buildings. What are the possibilities of architectural solutions and their benefits and negative aspects of this method? Reusing of concrete slabs is an alternative solution in architecture and construction for existing residential structures formed in the industrialized technology. The new building meets environmental standards and gives the possibility of savings at various stages of investment and operation of the building. As a result of those changes there has been a general improvement in quality of life, health conditions of the building estate and its positive image on the background of development of residential areas of the city. The problem of temporality in architecture appears here in the terms of transformation of social and environmental condition, as following the changing standards and the needs of modern life. The use of this method in Poland is difficult to achieve. However, it can form the basis for considerations of research in this field.

Keywords: residential buildings, architecture, reuse, housing environment

DOI: $10.7862 / \mathrm{rb} .2016 .281$

Przestano do redakcji: $25.06 .2016 r$.

Przyjęto do druku: 20.12.2016 r. 